\title{
Influence of Processing on the Microstructure and Properties of CoCrMoSi Alloy PTA Coatings
}

\author{
R.G. Bohatch ${ }^{1}$, J.N. Athayde ${ }^{1}$, J.C.M. Siqueira², A.S.C.M. D'Oliveira² ${ }^{2}$ A. Scheid ${ }^{2}$ \\ 1 Programa de Pós-Graduação em Engenharia Mecânica - PGMec, Universidade Federal do Paraná - UFPR, Curitiba, PR, Brazil. \\ 2 Universidade Federal do Paraná - UFPR, Curitiba, PR, Brazil.
}

Received: 14 Apr., 2015

Accepted: 12 July, 2015

E-mail: scheid@ufpr.br (AS)
Abstract: Wear performance as well as the low toughness of CoCrMoSi alloys is associated with the presence of Laves phase. In light of this, alloying elements have been altered in order to reduce the brittleness of newly-cast alloys. This study evaluated coatings by Plasma Transferred Arc (PTA) with different interactions with the AISI 316L substrate. The higher the dilution, it was hypothesized, the higher Iron, Chromium and Nickel contents proceeding from substrate and, therefore, the lower hard Laves phase fraction. Coatings were characterized by light and scanning electron microscopy, X-ray diffraction and Vickers hardness. Wear behavior was assessed by pin-on-disc and ball-on-flat tests. Laves phase and Cobalt solid solution eutectic lamellar microstructure was observed for coating processed with $120 \mathrm{~A}$ (18\% dilution). The chemical composition was displaced to hypoeutectic, showing Cobalt solid solution dendrites and interdendrictic eutectic lamellar for the coatings processed with higher current intensity $(150$ / 180A), due to the higher interaction with the substrate (26/38\% dilution). Dilution increased with the deposition current, causing hardness to decrease from $702-526 \mathrm{HV}_{0.5}$. Wear mass loss rate increased by up to $41.7 \%$ and friction coefficient $(\mu)$ ranged from $0.45-1.06$ as the chemical composition changed.

Key-words: CoMoCrSi alloy; Plasma transferred arc; Dilution; Microstructure; Wear behavior.

\section{Influência do Processamento sobre a Microestrutura e Propriedades de Revestimentos da liga CoCrMoSi por PTA}

Resumo: O desempenho em desgaste e a tenacidade das ligas CoCrMoSi estão associados à presença de fase de Laves. Neste sentido, o teor de elementos de liga vem sendo alterado para reduzir a fragilidade em algumas ligas recentemente propostas. O presente estudo avaliou revestimentos por Plasma com Arco Transferido (PTA) para diferentes graus de interação com o substrato de aço AISI 316L. Por hipótese, uma maior diluição promoverá maior teor de ferro, cromo e níquel oriundos do substrato e, portanto, uma menor fração de fase dura de Laves. Os revestimentos foram caracterizados por microscopia ótica e eletrônica e varredura, difração de raios-X e dureza Vickers. O comportamento em desgaste foi avaliado a partir de ensaios tipo pino sobre disco e esfera sobre superfície plana. Microestrutura eutética lamelar composta por fase Laves e solução sólida em Cobalto foi observada para a deposição com corrente de 120 A (18\% diluição). A composição química foi deslocada para hipoeutética, mostrando dendritas de solução sólida em Cobalto e região eutética lamelar para os revestimentos depositados com correntes de 150 e 180 A (26 e 38\% diluição). A diluição aumentou com a corrente e deposição, levando à redução na dureza de $702-526 \mathrm{HV}_{0.5}$. A taxa de perda de massa em desgaste aumentou em $41.7 \%$ enquanto o coeficiente de atrito $(\mu)$ variou entre 0.45 - 1.06 à medida que a composição química foi alterada.

Palavras-Chave: Liga CoMoCrSi; Plasma com arco transferido; Diluição; Microestrutura; Comportamento em desgaste.

\section{Introduction}

High performance coatings are applied to protect components that operate under aggressive environments, in order to reduce material cost and maintenance stoppages. A recent review of Plasma Transferred Arc (PTA) has highlighted the features that make the technique an attractive and competitive one [1].

In PTA processing, Co-based alloys are utilized to increase service life of mechanical components, including valves and valve seats, bearings and bushings, sleeves, dies and punches, as for example in Hot Dip Galvanizing pot hardware. Due to their ability to 
withstand wear in corrosive mediums because of their high resistance to corrosion, such alloys find application in chemical, petrochemical and steelmaking facilities. Moreover, Chromium acts as a solid solution strengthener and increases the corrosion resistance. However, service condition involving corrosion-wear phenomena is still a challenge. Corrosion-wear can cause the loss of surface material as a result of mechanical-chemical interaction, and the resulting debris will cause the reduction in the service life, as observed on Hot-Dip Galvanizing bearings [2-4].

The Co-based CoCrMoSi system has been shown to produce better results than carbides reinforced alloys under harsh environments. This alloy system can display a hypereutectic composition comprised of a primary Laves phase and a lamellar eutectic phase [5]. Tribaloy T400 alloy exhibits hypereutectic chemical composition and the microstructure is comprised of primary intermetallic Laves phase and lamellar eutectic. The Laves hexagonal close-packed (hcp) structure contains $\mathrm{Co}, \mathrm{Mo}$ and $\mathrm{Si}$, as a $\mathrm{Co}_{3} \mathrm{Mo}_{2} \mathrm{Si}$ and/or CoMoSi stoichiometry compound. Lower volume fraction of Laves phase is obtained reducing Chromium and Silicon content on the cast T400 alloy. So, higher ductility and toughness is obtained for tribaloy alloys, as previously reported [5-8].

Despite producing better results for wear and corrosion-wear, CoCrMoSi alloys have limited ductility and toughness due to the hard intermetallic Laves phase fraction, which can compromise processing. As a possible solution, this study examined the effect of dilution on CoCrMoSi coatings by Plasma Transferred Arc in order to reduce the excessively brittle nature of Tribaloy T400. The higher the dilution, it was hypothesized, the higher Iron, Chromium and Nickel contents proceeding from substrate. As a result, Silicon and Molybdenum contents would reduce proportionally and, therefore, the hard Laves phase fraction. As processing parameters can significantly alter the chemical composition of the T400 alloy atomized powder, understanding the interaction with the substrate is of great relevance to predicting the features and performance of the coatings. Therefore, the aim of this study is to assess the relationship between dilution level and microstructure, hardness and wear behavior.

\section{Material and Methods}

Atomized CoCrMoSi alloy (Tribaloy T400) with grain size ranging from 90-150 $\mu \mathrm{m}$ was Plasma Transferred Arc (PTA) deposited, as shown in Table 1. The current intensity was varied from 120-180A to increase the interaction with the substrate, which altered the Silicon and Molybdenum contents, reducing therefore the fraction of Laves brittle phase $[6,7,9]$. As toughness improves, wear performance is expected to reduce.

The deposition of a $100 \mathrm{~mm}$ length single track on $12,5 \mathrm{~mm}$ thick AISI 316L stainless steel plate was carried out (Table 2). Characterization was performed in the middle of the deposited layer.

Table 1. Chemical Composition of the materials used (wt \%).

\begin{tabular}{lccccccccc}
\hline \multicolumn{1}{c}{ Alloy } & Co & Cr & w & Mo & C & Fe & Ni & Si & Mn \\
CoMoCrSi & Bal. & 8.8 & $\ldots .$. & 29.1 & 0.05 & 0.4 & 0.6 & 2.4 & $\ldots$ \\
\hline Substrate & $\mathbf{C}$ & $\mathbf{M n}$ & $\mathbf{S i}$ & $\mathbf{P}$ & $\mathbf{S}$ & $\mathbf{C r}$ & $\mathbf{N i}$ & $\mathbf{M o}$ & $\mathbf{A l}$ \\
AISI 316L & 0.02 & 1.35 & 0.43 & 0.03 & 0.01 & 16.78 & 10.12 & 2.13 & 0.002 \\
\hline
\end{tabular}

Table 2. Plasma Transferred Arc processing parameters.

\begin{tabular}{lc}
\hline \multicolumn{1}{c}{ Parameters } & Values \\
Shielding gas (I/min) & 2 \\
Protection gas (I/min) & 15 \\
Powder feeding gas (I/min) & 2 \\
Protection, shielding and feeding gas & Argon \\
Main arc current $(\mathrm{A})$ & $120,150,180$ \\
Powder feed rate & Constant in volume \\
Travel speed (mm/min) & 100 \\
Distance torch / substrate (mm) & 10 \\
Electrode diameter $(\mathrm{mm})$ & 3.13 \\
Electrode set back $(\mathrm{mm}) /$ Electrode tip angle $\left(^{\circ}\right)$ & $10 / 30^{\circ}$ \\
\hline
\end{tabular}


Visual inspection was performed on coatings surface to evaluate the presence of welding defects. Optical microscopy on the transverse cross section of the deposits was also carried out. The track geometry was measured by light microscopy for reinforcement thickness $(\mathrm{t})$, width $(\mathrm{W})$ and wettability angle $(\Theta)$, as seen in Figure 1. The interaction with the substrate (dilution) was determined on the transverse cross-section by the ratio between the melted area of the substrate and the total melted area.

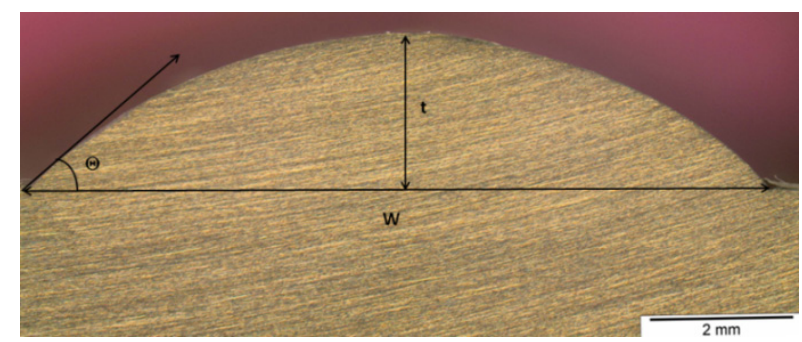

Figure 1. Geometry of welding overlays: thickness (t), width $(w)$ and wettability angle $(\Theta)$.

With regard to the description of the microstructure and volume fraction measurement, the coatings were characterized in the as-deposited condition with Olympus Soft Imaging Solutions • software. X-ray diffraction (XRD) analysis on the top surface of the coatings was carried out with $\mathrm{K}_{\alpha} \mathrm{Cu}$ radiation from $20-120^{\circ}$ and exposure channel of $1 \mathrm{~s}$. Coatings hardness was measured on the transverse cross-section under $4.9 \mathrm{~N}$ load and results as an average of 10 measurements.

The effect of processing on wear performance was evaluated by abrasive sliding tests on pin-on-disc sliding apparatus. Pins measuring $4 \times 4 \mathrm{~mm}$ were machined out of the deposited coatings. Samples slide against silicon carbide paper (\#220) assembled on a 63 HRC hardness metal disc with an axial load of $4.9 \mathrm{~N}$ and tangential speed of $1.5 \mathrm{~m} / \mathrm{s}$. The wear behavior was measured by way of the mass loss, weighing the samples before every test and after each $250 \mathrm{~m}$ sliding distance at room temperature. The friction coefficient was measured utilizing ball-on-flat sliding test against $6 \mathrm{~mm}$ diameter $\mathrm{ZrO}_{2}$ sphere with $4.9 \mathrm{~N}$ axial load, $150 \mathrm{~m}$ total distance and $20 \mathrm{~mm} / \mathrm{s}$ maximum travel speed.

\section{Results and Discussion}

\subsection{Visual inspection}

A visual inspection of the coatings revealed a smooth surface with no welding defects. Evidence of spatter, undercut, porosity or cracks was not found. The findings of this macroscopic evaluation are consistent with the prediction of the literature [8]. However, limited data are available regarding the interaction of the Tribaloy T400 with the substrate (dilution) and its effect on the chemical composition, microstructure and properties of the coatings $[5,10]$.

Differences in track geometry due to the current intensity were measured. Coatings processed as a single track with 120 A exhibited the lowest wettability, confirmed by the highest wettability angle $(\Theta)$ and reinforcement thickness (t), and shallowest width compared to that processed with the higher current (180A), as shown in Table 3. As deposition current increases, dilution levels rise from 18 - 38\%, as a result of the higher temperature of the system (alloy and substrate). Dilution and deposition current followed linear correlation, as can be seen in Table 3 . The higher interaction with the substrate induces variation in the chemical composition of the coatings [11,12].

\subsection{Interaction with the substrate and microstructure}

X-ray diffraction analysis showed that Cobalt solid solution (Co SS: FCC), CoMoSi / $\mathrm{Co}_{3} \mathrm{Mo}_{2}$ Si Laves phase and $\mathrm{Co}_{2} \mathrm{Mo}_{3} / \mathrm{Co}_{7} \mathrm{Mo}_{6}$ (Co-Mo intermetallics) are the main phases formed for each deposition current. It might suggest that Iron, Chromium and Nickel contents variation due to dilution did not alter the developed phase, but just their proportion, following the same trend as observed recently on cast alloy, as shown in Figure 2 [5,7,10]. 
The dilution displaced the chemical composition of coatings and altered the hypereutectic comprised of primary Laves phase and eutectic lamellar (Co SS + Laves phase) microstructure reported for cast CoCrMoSi T400 alloy to eutectic and hypoeutectic composition, seen in Figure 3, Figure 4 and Figure $5[7,8]$. For $18 \%$ dilution, an eutectic lamellar microstructure consisting of Laves phase and Cobalt solid solution was observed. The chemical composition of the coatings was altered as a result of higher Iron, Chromium and Nickel content.

A new cast alloy named T401 was developed based on T400, to improve toughness especially. Chemical composition was altered by reducing Silicon to the half, Molybdenum to $22.8 \mathrm{wt} \%$ and Chromium was doubled, changing the composition to a hypoeutectic. Chromium is mostly in Cobalt solid solution while Silicon is concentrated in Laves phase. Molybdenum can be in both Cobalt solid solution and Laves phase [7]. Hence, the interaction with the AISI 316L steel substrate on the microstructure of T400 alloy and its effect on the hardness and wear behavior of the coatings was investigated.

Table 3. Geometry and dilution of welding track.

\begin{tabular}{clccc}
\hline Substrate & \multicolumn{1}{c}{ Parameter } & 120 A & 150 A & 180 A \\
AISI 316L & Dilution $D(\%)-\left(\mathrm{D}=\left(0.33^{*}(\mathrm{~A})-22.6\right) /\left(\mathrm{R}^{2}=0.99\right)\right.$ & 18 & 26 & 38 \\
& Thickness, $\mathrm{t}(\mathrm{mm})$ & 2.7 & 2.4 & 2.1 \\
& Width, $W(\mathrm{~mm})$ & 7.7 & 11.2 & 12.0 \\
& Wettability Angle, $\Theta\left({ }^{\circ}\right)$ & 83.0 & 49.4 & 37.8 \\
\hline
\end{tabular}

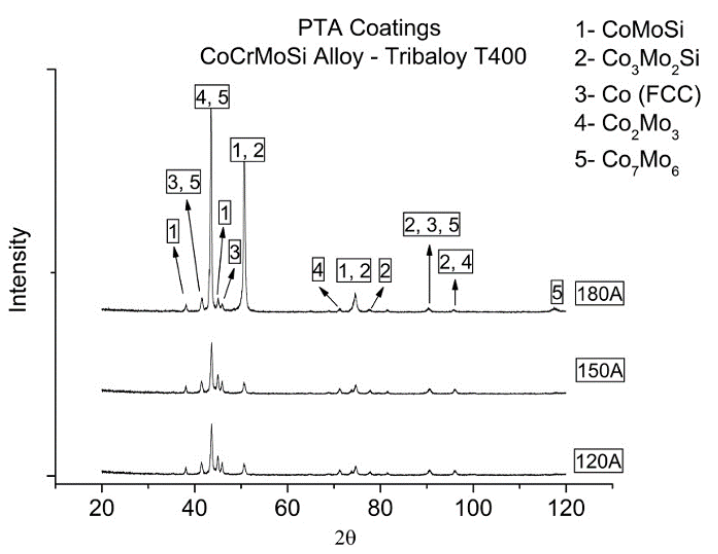

Figure 2. X-ray diffraction analysis on CoCrMoSi coatings deposited with 120, 150 and $180 \mathrm{~A}$.
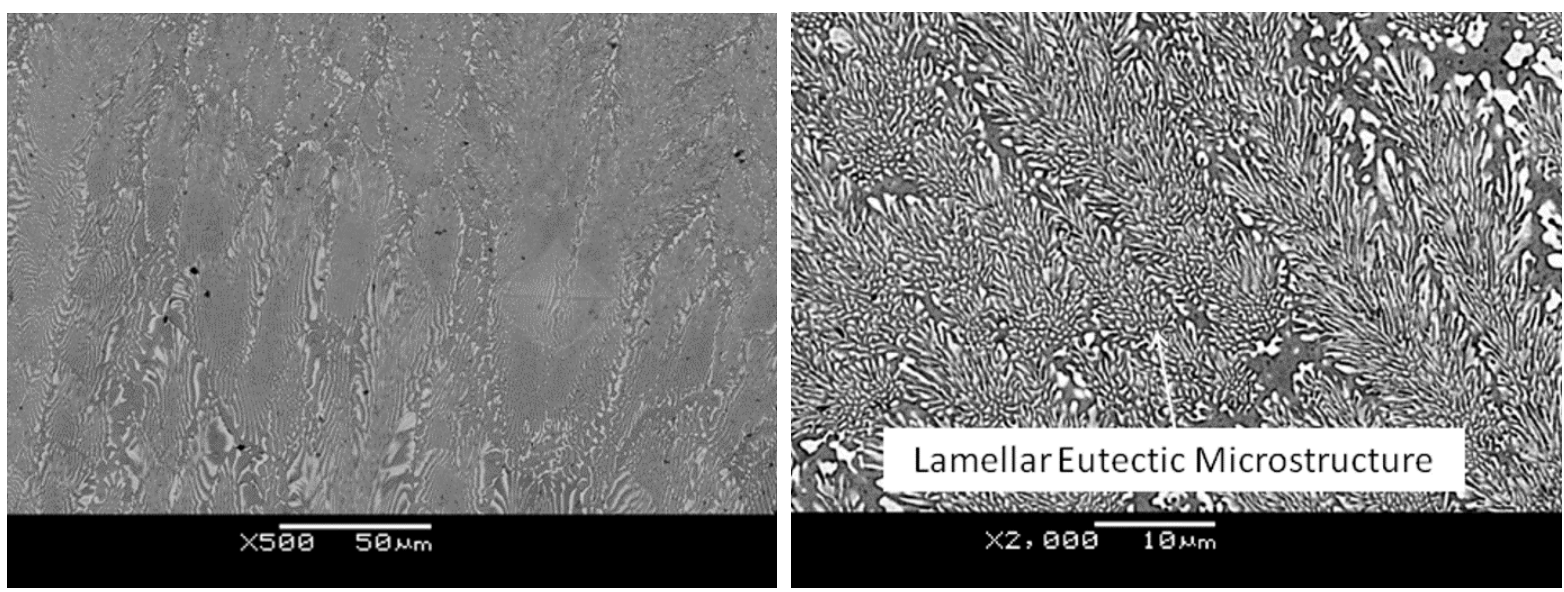

Figure 3. Eutectic microstructure of CoCrMoSi PTA coatings (120 A). 

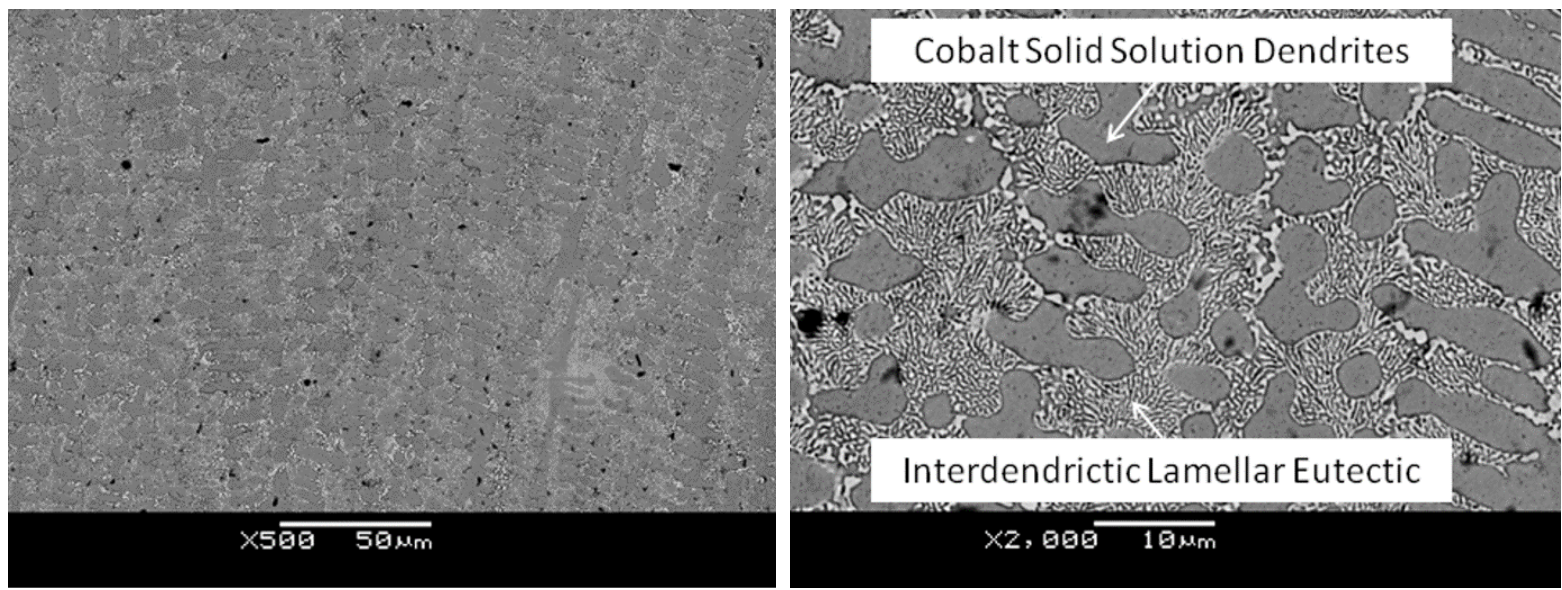

Figure 4. Hypoeutectic microstructure of CoCrMoSi PTA coatings (150 A).
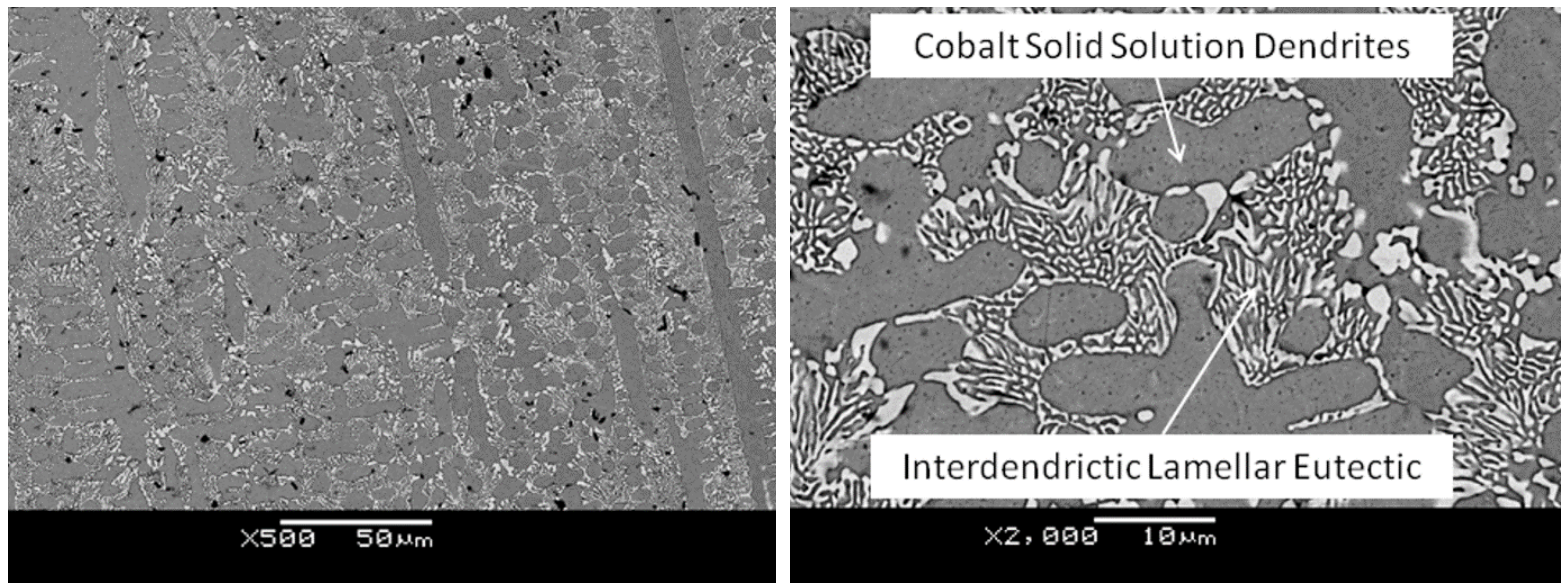

Figure 5. Hypoeutectic microstructure of CoCrMoSi PTA coatings (180 A).

The main elements of AISI 316L steel substrate are Iron, Chromium and Nickel and, therefore, it is expected that the presence of these elements on coatings due to dilution alter the proportion of Cobalt solid solution phase on the microstructure of the coatings. The interaction with the substrate was directly related to dilution, as previously reported in the literature [12].

The chemical composition of the T400 alloy coatings was displaced to hypoeutectic for dilutions of 26 and $38 \%$. This induced a microstructure of Cobalt solid solution dendrites and interdendrictic eutectic lamellar region. The chemical composition of the coatings with the highest interaction with the substrate showed similar solidification microstructure compared to the newly developed cast T401 alloy, thus confirming the distribution of elements from substrate (Fe, $\mathrm{Cr}$ and $\mathrm{Ni}$ ) mostly as Cobalt solid solution [7].

Since Iron, Chromium and Nickel form substitutional solid solution in Cobalt, the composition of the coatings changed from hypereutectic T400 [8] to eutectic and hypoeutectic coatings as dilution increased. The lowest dilution $(18 \%)$ reduced Silicon and Molybdenum contents leading to the primary Laves phase suppression and to a fully eutectic microstructure. Hypoeutectic microstructure exhibiting Cobalt solid solution dendrites and interdendrictic eutectic lamellar was observed for dilutions of 26 and 38\%, as can be seen in Figure 6 and Table 4.

\subsection{Effect of microstructure on hardness and wear performance}

CoCrMoSi alloys are intermetallic reinforced materials and the chemical composition of these alloys is the most important factor dictating Laves phase volume fraction and, thus, mechanical properties [8]. In this context, as important differences in chemical composition occurred during processing altering the microstructure, changes in the properties of the coatings are expected. 
Higher dilution led to a microstructure with a reduced intermetallic Laves phase, causing hardness to decrease, as shown in Figure 7. The most significant reduction of the eutectic volume fraction ( $40 \%$ reduction) was observed comparing 18\% (120 A) and 26\% (150 A) dilution, as well as the largest decrease in hardness. Furthermore, the higher Iron content in solid solution presented a deleterious effect, reducing the hardness. For the higher dilution $(38 \%)$ of the coatings processed with $180 \mathrm{~A}$, eutectic volume fraction decreased even more (6\%) leading to the lowest hardness. Thus, the hardness was influenced first by the volume fraction of the hard phase (eutectic lamellar containing Laves phase) followed by the reduction of alloying in solid solution, following the same behavior previously observed on cast alloy $[6,7,10]$.

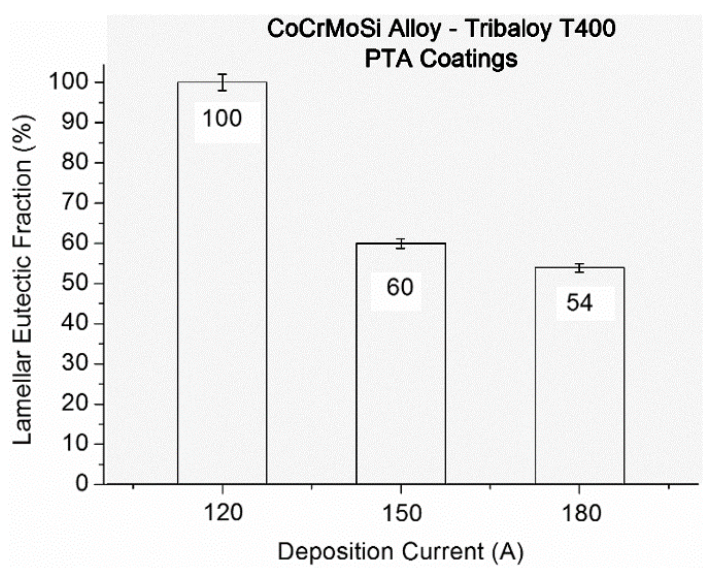

Figure 6. Volume fraction of lamellar eutectic.

Table 4. Chemical distribution measured on the microstructure of CoCrMoSi T400 alloy coatings (wt \%).

\begin{tabular}{|c|c|c|c|c|c|c|c|}
\hline $\begin{array}{c}\text { Current } \\
\text { (A) }\end{array}$ & Alloy Powder & $\begin{array}{c}\mathrm{Si} \\
2.4\end{array}$ & $\begin{array}{l}\text { Mo } \\
29.1\end{array}$ & $\begin{array}{l}\text { Co } \\
\text { Bal. }\end{array}$ & $\begin{array}{l}\mathrm{Cr} \\
8.8\end{array}$ & $\begin{array}{c}\mathrm{Fe} \\
\end{array}$ & $\mathbf{N i}$ \\
\hline \multirow[t]{2}{*}{120} & Eutectic & 2.23 & 29.42 & Bal. & 9.02 & 9.75 & \\
\hline & Cobalt Solid Solution & ---- & 14.04 & Bal. & 12.30 & 13.42 & 3.20 \\
\hline \multirow[t]{2}{*}{150} & Eutectic & 2.12 & 28.40 & Bal. & 9.32 & 18.08 & \\
\hline & Cobalt Solid Solution & ---- & 11.84 & Bal. & 13.44 & 21.08 & 4.14 \\
\hline \multirow[t]{2}{*}{180} & Eutectic & 2.08 & 22.56 & Bal. & 11.08 & 26.63 & \\
\hline & Cobalt Solid Solution & ---- & 11.54 & Bal. & 14.23 & 27.28 & 4.05 \\
\hline
\end{tabular}

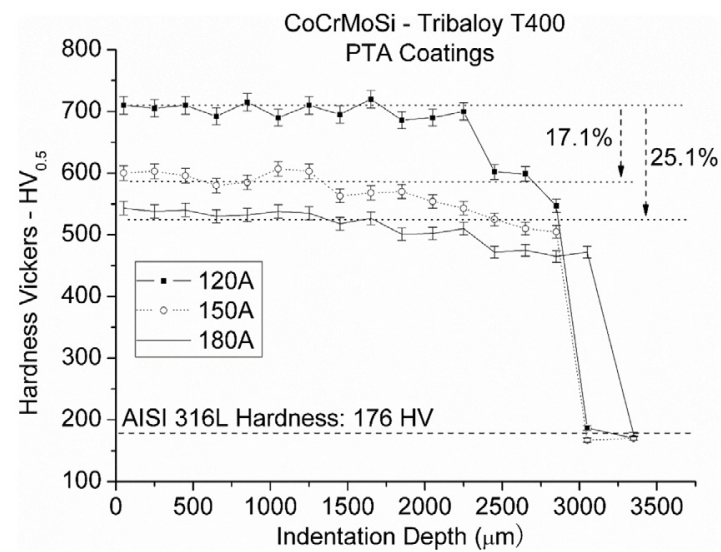

Figure 7. Vickers Hardness of coatings in the as-deposited condition. 
Microstructure of the as-deposited condition provides a better understanding of the hardness variation. Co-based T400 coatings mean hardness ranged from $702-526 \mathrm{HV}_{0.5}$, as a result of increasing dilution which increased the volume of the lower hardness phase, Cobalt solid solution. Higher deposition current led to higher Iron, Chromium and Nickel contents on the melted pool, reducing Molybdenum proportionally and, therefore, the solid solution hardening effect (Table 4). The microstructure and phase distribution observed as well as the measured coatings hardness, are consistent with what has been predicted in the literature [7].

Coatings wear behavior was assessed to evaluate the response of the T400 in a hardfacing condition, according to the interaction degree with the substrate (dilution). The coatings were tested in the as-deposited condition with constant test parameters. The higher current intensity $(180 \mathrm{~A})$ changes the microstructure and hardness, and led to an increase in mass loss rate, seen in Figure 8a. Under tested conditions, a linear correlation between sliding distance and mass loss was measured by varying the sliding distance [11]. As expected, the result abided by Holm-Archard equation which establishes that the wear volume is inversely proportional to the hardness [13].
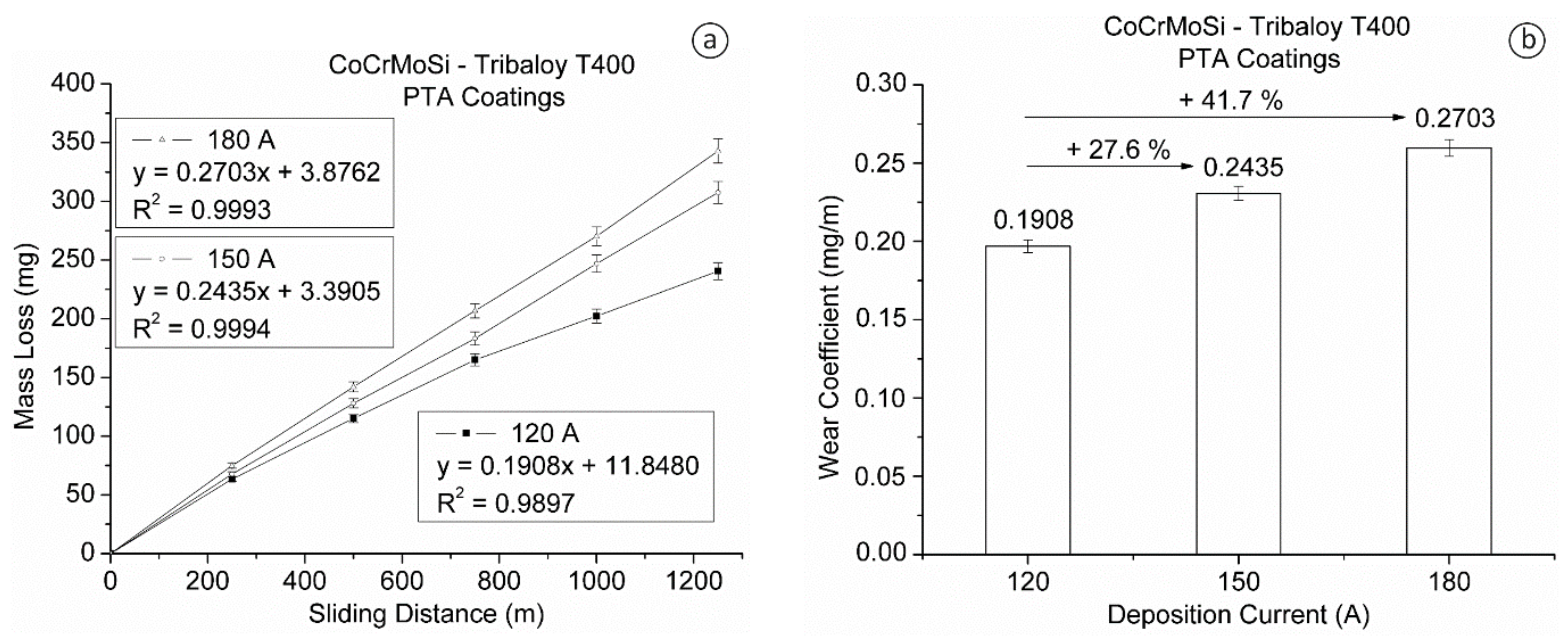

Figure 8. Wear curves for CoCrMoSi alloy coatings (a) and Wear coefficient (b).

Differences in the chemical composition of the coatings influenced wear mass loss rate. The lowest wear rate $(0.1908 \mathrm{mg} / \mathrm{m})$ was obtained for dilution of $18 \%$. The mass loss rate increased to $0.2435 \mathrm{and} 0.2703 \mathrm{mg} / \mathrm{m}$ as dilution reached 26 and 38\%, respectively. Better wear behavior can be attributed to the volume fraction of the eutectic lamellar and, therefore, with the hard Laves phase fraction [7-9].

Chemical composition displacement to hypoeutectic led to higher volume fraction of Cobalt solid solution and higher Iron content, inducing poor wear performance. Results were in line with previous reports obtained on the cast CoCrMoSi T400 alloy [10]. Dilution increase from $18-26 \%$ promoted an increase of $27.6 \%$ on wear mass loss rate and, finally, $38 \%$ dilution resulted in the increase of $41.7 \%$ on wear rate (Figure $8 \mathrm{~b}$ ).

The eutectic microstructure developed the lower friction coefficient $(\mu=0.45)$, while the mixture of Cobalt solid solution dendrites and interdendrictic eutectic lamellar areas presented the higher values $(\mu=0.90$ and $\mu=1.06)$, as can be seen in Figure 9. Forged CoCrMo alloy presented friction coefficient $(\mu)$ varying from 1.0 and 1.1 against ceramic ball, while cast T400C alloy presented 0.6 [14-16].

The eutectic microstructure of the coatings showed that the wear debris is a result of detaching small lamellar areas of the hard intermetallic Laves phase, seen in Figure 10a. EDS analysis on the wear debris showed Molybdenum ranging from 22 to 28 wt\%, Silicon from 1,5 to 2,2 wt\% and Chromium, Iron and Cobalt varying according the dilution with the substrate. It indicated the wear debris is probably from the eutectic detached areas. 


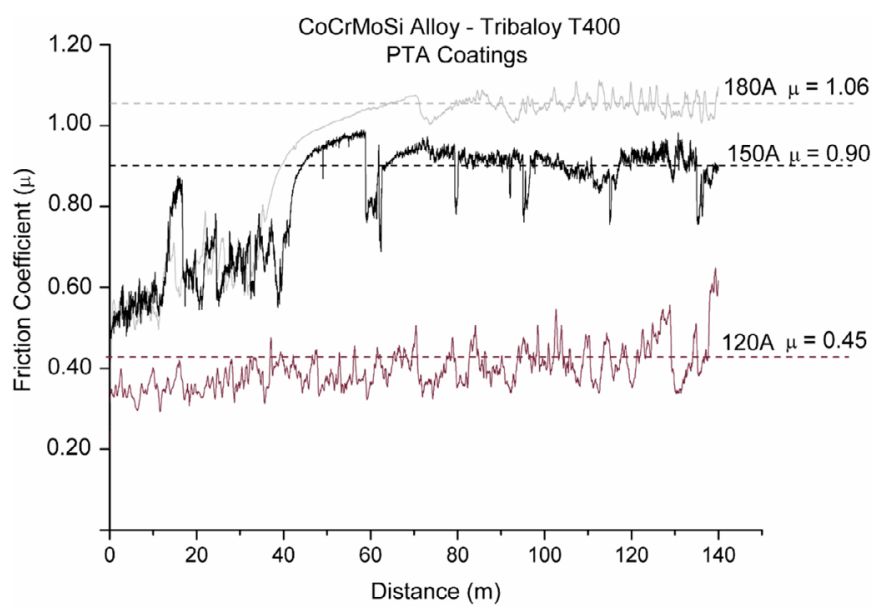

Figure 9. Ball-on-flat sliding friction coefficient for CoCrMoSi alloy coatings.
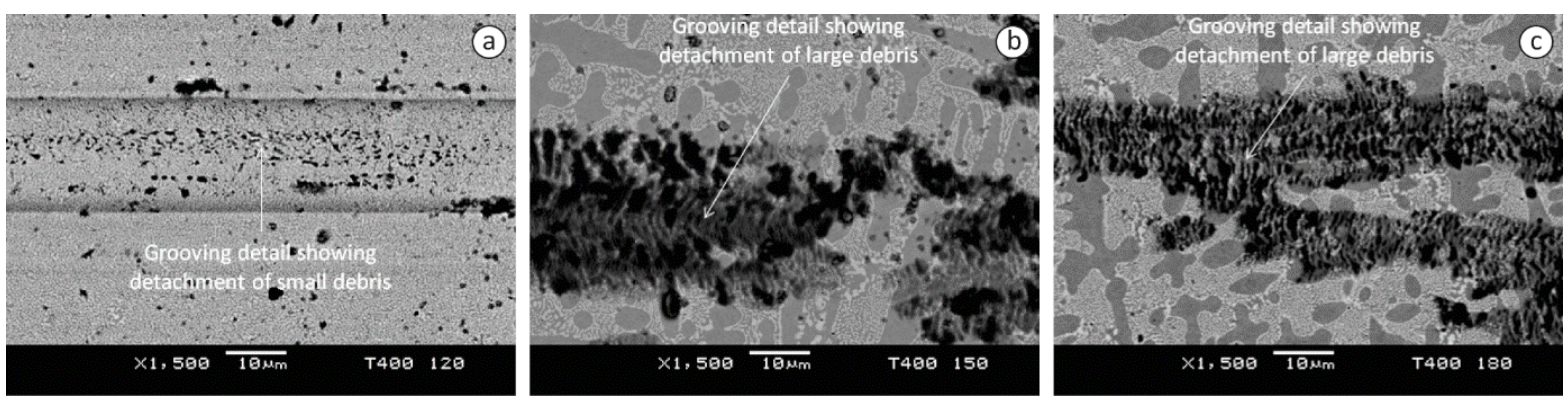

Figure 10. Grooving details of ball-on-flat sliding tracks: (a) $120 \mathrm{~A}$ (b) $150 \mathrm{~A}$ and (c) $180 \mathrm{~A}$.

The Cobalt solid solution areas induced a higher mass loss rate. Moreover, the Cobalt solid solution free of Laves changed detaching intensity because this phase does not adequately support the interdendrictic eutectic lamellar, what was worn out as large debris (as observed on sliding track of the ball-on-flat test), as shown in Figure $10 \mathrm{~b}$ and Figure 10c.

The interaction with the substrate by PTA processing significantly altered the chemical composition of the coatings. It displaced the composition from hypereutectic to eutectic or hypoeutectic, depending on the degree of dilution. The Laves phase volume fraction and Cobalt solid solution alloying determined the hardness of the coatings. Therefore, the wear behavior was influenced showing an increase in mass loss rate and friction coefficient.

\section{Conclusions}

This study analyzed the effect of deposition current (dilution) on the microstructure, hardness and wear performance of the Co-based T400 alloy coatings by PTA on AISI 316L. The main contributions presented are as follows:

- The deposition current affects the interaction with the substrate, which in turn affects the amount of Iron-Chromium-Nickel on coatings reducing Molybdenum and Silicon proportionally, displacing chemical composition of CoCrMoSi alloy from hypereutectic to eutectic or hypoeutectic.

- The higher the interaction with the substrate, the lower the coatings hardness due to the reduction of Laves phase volume fraction and also Cobalt solid solution alloying.

- Hypoeutectic microstructure presented lower Laves phase volume fraction and solid solution alloying, leading to a poorer wear performance of the CoCrMoSi alloy coatings. Differences also negatively affected the friction coefficient and the intensity of detachment of wear debris. 
- For the specific CoCrMoSi alloy system, the deposition current can be designed to control its microstructure and properties. Higher dilution reduces the amount of alloying elements (Mo and Si), confirming the principles developed to obtain higher ductility cast Tribaloy alloys.

\section{References}

[1] Gonçalves R. H., Dutra J. C. PTA-P Process - a literature review as basis for innovations. Part 1 of 2: constructive elements. Soldagem \& Inspeção. 2013;17(1):76-85.

[2] Donachie MJ, Donachie SJ. Superalloys: a technical guide. 2nd ed. Ohio: ASM International; 2002. p. 25-38.

[3] Kim H, Yoon B, Lee C. Sliding wear performance in molten $\mathrm{Zn}-\mathrm{Al}$ bath of cobalt-based overlayers produced by plasma transferred arc weld-surfacing. Wear. 2003;254(5-6):408-414. http://dx.doi.org/10.1016/S0043-1648(03)00186-8.

[4] Hou QY, Gao JS, Zhou F. Microstructure and wear characteristics of cobalt-based alloy deposited by plasma transferred arc weld surfacing. Surface and Coatings Technology. 2005;194(2-3):238243. http://dx.doi.org/10.1016/j.surfcoat.2004.07.065.

[5] Scheid A, D'Oliveira ASCM. Analysis of PTA hardfacing with CoCrWC and CoCrMoSi alloys. Soldagem \& Inspeção. 2013;18(4):322328. http://dx.doi.org/10.1590/S0104-92242013000400004.

[6] Przybylowicz J, Kusinski J. Laser cladding and erosive wear of Co-Mo-Cr-Si coatings. Surface and Coatings Technology. 2000;125(1-3):13-18. http://dx.doi.org/10.1016/S02578972(99)00563-0.

[7] Liu R, Xu W, Yao MX, Patnaik PC, Wu XJ. A newly developed Tribaloy alloy with increased ductility. Scripta Materialia. 2005;53(12):1351-1355. http://dx.doi.org/10.1016/j. scriptamat.2005.08.033.

[8] Xu W, Liu R, Patnaik PC, Yao MX, Wu XJ. Mechanical and Tribological properties of newly developed Tribaloy alloys. Materials Science and Engineering A. 2007;452-453:427-436. http://dx.doi.org/10.1016/j.msea.2006.10.088.
[9] Gao F, Liu R, Wu XJ. Triballoy alloy reinforced tin-bronze composite coating for journal bearing applications. Thin Solid Films. 2011;519(15):4809-4817. http://dx.doi.org/10.1016/j. tsf.2011.01.035.

[10] Scheid A, D'Oliveira ASCM. Effect of processing on microstructure and properties of CoCrMoSi alloy. Materials Research. 2013;16(6):1325-1330. http://dx.doi.org/10.1590/S151614392013005000120.

[11] Gonçalves RH, Dutra JC. PTA-P Process - a literature review as basis for innovations. Part 2 of 2: powder thermal and kinematic behavior, process parameters and consumables. Soldagem \& Inspeção. 2012;17(2):173-183.

[12] Antoszczyszyn TJ, Paes RMG, D’Oliveira ASCM, Scheid A. Impact of dilution on the microstructure and properties of Ni-based 625 alloy coatings. Soldagem e Inspeção. 2014;19(2):134-144. http://dx.doi.org/10.1590/0104-9224/SI1902.05.

[13] Rabinowicz E. Friction and wear of materials. 2nd ed. New York: Wiley Interscience; 1995. p. 143-190.

[14] Çelik A, Bayrak Ö, Alsaran A, Kaymaz Í, Yetim AF. Effects of plasma nitriding on mechanical and tribological properties of CoCrMo alloy. Surface and Coatings Technology. 2008;202(11):24332438. http://dx.doi.org/10.1016/j.surfcoat.2007.08.030.

[15] Wei R, Booker T, Rincon C, Arps J. High-intensity plasma ion nitriding of orthopedic materials Part I. Tribological study. Surface and Coatings Technology. 2004;186(1-2):305-313. http://dx.doi.org/10.1016/j.surfcoat.2004.02.052.

[16] Jiang K, Liu R, Chen K, Liang M. Microstructure and tribological properties of solution-treated tribaloy alloy. Wear. 2013;307(12):22-27. http://dx.doi.org/10.1016/j.wear.2013.08.018. 